Research Article

\title{
First day bilirubin as a predictor of development of significant jaundice in term healthy neonates: a tertiary care hospital based study
}

\author{
Malik Shakir Hussain ${ }^{1}$, Imran Ahmad Gattoo ${ }^{2} *$, Bilal Ahmad Najar ${ }^{2}$, Muddasir Maqbool ${ }^{2}$
}

${ }^{1}$ Lecturer, ${ }^{2}$ Registrar, Post Graduate Department of Paediatrics, Government Medical College, Srinagar, J \& K, India

Received: 04 August 2015

Accepted: 20 August 2015

*Correspondence:

Dr. Imran Ahmad Gattoo,

E-mail: immz24@gmail.com

Copyright: ( $)$ the author(s), publisher and licensee Medip Academy. This is an open-access article distributed under the terms of the Creative Commons Attribution Non-Commercial License, which permits unrestricted non-commercial use, distribution, and reproduction in any medium, provided the original work is properly cited.

\section{ABSTRACT}

Background: Neonatal jaundice is common and usually benign self-limited condition, but if severe can cause severe neurological damage. ${ }^{1}$ This prospective study was undertaken to determine the critical serum bilirubin level to predict the significant hyperbilirubinemia in healthy term new-borns based on the serum bilirubin measurement made within 24 hours of postnatal life. Present study was done to study the first day bilirubin as a predictor of development of significant jaundice in healthy term neonates.

Methods: The present study was conducted in the post graduate department of paediatrics Government Medical College Srinagar, tertiary care referral hospital. Total of 152 healthy term new-borns were included in the study. Micro capillary sample was taken on heel prick and centrifuge. Bilirubin estimation was done spectophotometrically using twin beam method (575-455) wave length bilinmicrometer. The infants were followed up clinically every 12 hours after initial bilirubin estimation till discharge the babies were recalled after discharge at 5 days of age. This study is a Prospective observational study.

Results: Initial bilirubin estimation was done on first postnatal day, and the range of initial bilirubin estimation was between $2.9-8 \mathrm{mg} / \mathrm{dl}$. Clinically detectable jaundice was present in 110 (72.36\%) patients. Out of 152 new-borns, 101 $(66.44 \%)$ with serum bilirubin $<6 \mathrm{mg} / \mathrm{dl}$ only 1 developed significant hyperbilirubinemia, were as $51(33.52 \%)$ newborns who had serum bilirubin $>6 \mathrm{mg} / \mathrm{dl} 13$ (25.46\%) developed significant hyperbilirubinemia.

Conclusions: The present study found that a total serum bilirubin level of $\leq 6 \mathrm{mg} / \mathrm{dl}$ can be used to predict decreased risk for subsequent hyperbilirubinemia (TSB $>17 \mathrm{mg} / \mathrm{dl}$ ) with a sensitivity of $92.8 \%$ and negative predictive value of $99 \%$. Such infants could thus be discharged early without need to follow up for hyperbilirubinemia later.

Keywords: Hyperbilirubinemia, Incompatibility, Kernicterus, Sepsis, Oxytocin

\section{INTRODUCTION}

Neonatal jaundice is common and usually benign selflimiting condition, but if severe can cause severe neurological damage. ${ }^{1}$ Jaundice comes from the French word jaune which means yellow. ${ }^{2}$ When it is said that a baby is jaundiced it simply means babies skin appears yellow, due to the accumulation of non-polar lipid soluble bilirubin pigment in skin. ${ }^{3}$ Bilirubin is derived from the breakdown of heam containing proteins in the reticuloendothelial system. ${ }^{4}$ The normal new-born produces 6-10 mg of bilirubin per kilogram per day, as opposed to production of 3-4 mg per kg per day in adults, increased production of bilirubin in new-born is due to: ${ }^{4}$

1) Increased red cell volume per $\mathrm{kg}$ and decreased $\mathrm{RBC}$ survival.

2) Increased ineffective erythropoiesis.

3) Increased enterohepatic circulation.

4) Decreased uptake by the liver.

5) Defective conjugation. 
Most of the times jaundice in new-borns is a normal event and is not serious, jaundice disappears after few days even without any special treatment. ${ }^{2}$ Newborns appear jaundiced when serum bilirubin exceeds $5 \mathrm{mg} / \mathrm{dl}$ as opposed to adults who appear jaundiced at a Value above $2 \mathrm{mg} / \mathrm{dl}$. Jaundice is observed during the first week in $60 \%$ of term and $80 \%$ of preterm new-borns. It usually progresses in cephalocaudal direction 3 .

Neonatal jaundice is a concern for both parents as well as paediatricians, ${ }^{5}$ and is one of the most important reason of readmission after early discharge from the hospital. ${ }^{6}$ Concerns regarding jaundice have increased after reports of bilirubin induced brain damage healthy term infants even without any haemolysis or any other significant risk factor for the development of jaundice. ${ }^{7}$ Total Serum Bilirubin (TSB) in early days of life generally shows an increasing trend and some of these infants develop hyperbilirubenemia. ${ }^{8}$ One of the major concerns with early discharge of an infant is the occurrence of neonatal hyperbilirubinemia after the discharge. ${ }^{9}$

Failure to recognize the risks and delay in the appropriate care increase the chances of bilirubin induced brain damage. This puts the babies under the risk of impairment of future physical and mental development. ${ }^{9}$

If neonatal hyperbilirubinemia can be predicted at discharge then appropriate care seeking measures such as early follow- up visits, estimation of total serum bilirubin when needed and early initiation of phototherapy can be carried out. ${ }^{9}$ This prediction can identify infants for immediate intervention to decrease neonatal hyperbilirubinemia. ${ }^{9}$

Early discharge of healthy term new-borns has become a common practice because of medical and social reasons and economic constraints, however an association between the decreased length of stay and risk of readmission to the hospital has been previously seen, ${ }^{10,11}$ thus recognition, follow up and early treatment of jaundice has become more difficult as a result of very short hospital stay. Therefore it is difficult to predict which infants are at risk of significant and relatively late hyperbilirubinemia, and therefore there is an obvious need to implement follow up programs or to develop guidelines that will enable the physicians to predict or to identify which of the early discharged new-borns will develop significant hyperbilirubinemia. ${ }^{8}$

The current guidelines of American Academy of Paediatrics recommend the follow up of new-borns discharged within 48 hours of life at 2-3 days postnatally. ${ }^{1}$ However a complete follow up is not always possible because of the geography and climate of the area, personal safety or patient noncompliance and there is a need to identify new-borns who are at risk for developing significant hyperbilirubinemia as early as possible ${ }^{8}$.
The concept of prediction of jaundice offers an attractive option to pick up the babies at risk of neonatal hyperbilirubenemiaand follow them up closely. ${ }^{5}$

This prospective study was undertaken to determine the critical serum bilirubin level to predict the significant hyperbilirubinemia in healthy term new-borns based on serum bilirubin measurements made within 24 hours of postnatal life.

\section{Aims and objectives}

The present study was conducted in the post graduate department of paediatrics Government Medical College Srinagar, a tertiary care referral hospital from March 2014 to March 2015 for a period of one year.

1) To evaluate the predictive value of total serum bilirubin within 24 hours of post natal life in term new-borns to identify those new-borns.

2) Who do not develop significant hyperbilirubenemia subsequently and could be candidates for an early discharge?

3) Who do develop significant hyperbilirubenemia and subsequent management?

\section{METHODS}

The present study was conducted in the post graduate departments of paediatrics and obstetrics/gynaecology, Government Medical College, Srinagar, from March 2014 to February 2015 for one year. Ethical clearance was given by the ethical committee of the Medical College. Written informed consent was taken from the parents and guardian of the children for their participation in the study.

\section{Design:}

Prospective observational study.

\section{Inclusion criteria:}

Gestational age >35 weeks based on LMP and neonatal assessment based on expanded Ballard's score, absence of significant illness requiring neonatal intensive care unit admission $>12$ hours and absence of major congenital malformations

\section{Exclusion criteria:}

Sick new-borns, Rh haemolytic babies.

\section{Bilirubin estimation:}

Micro capillary sample was taken on heel prick and centrifuge at a rate of $10000 \mathrm{rpm}$ for five minutes.

Bilirubin estimation was done spectophotometrically using twin beam method (575-455) wave-length 
bilinmicrometer. It carried out rapid photometric analysis of total bilirubin undiluted serum through a haematocrit capillary tube used as an optical cell. The bilirubin determination was displayed as in $\mathrm{mg} / \mathrm{dl}$. Bilinmicrometer has high reliability and reproducibility compared to conventional Vander Berg's test that needs large blood sample size, lack of accuracy, reliability and reproducibility.

\section{Follow up}

The infants were followed up clinically every 12 hours after initial bilirubin estimation till discharge the babies were recalled after discharge at 5 days of age. In those babies were clinical assessment of bilirubin level was more than $10 \mathrm{mg} / \mathrm{dl}$ bilirubin estimation was repeated.

Hyperbilirubenemia was defined as total serum bilirubin level of $>17 \mathrm{mg} / \mathrm{dl}$.

\section{Sample size}

Assuming the incidence of hyperbilirubenemia to be 1 $3 \%$ in infants with TSB $<6 \mathrm{mg} / \mathrm{dl}$ on day one. It was estimated that a sample size of 150 infants was sufficient excluding drop outs.

\section{Observations}

A total of 160 new-borns fulfilled the criteria for the study. Out of 160 new-borns one patient developed sepsis, 7 patients were lost to follow up. Complete information was present on 152 infants only.

\section{RESULTS}

Table 1 is showing that out of 152 deliveries 120 $(75.65 \%)$ were caesarean deliveries and 32 (21.05\%) were normal vaginal deliveries.

\section{Table 1: Mode of delivery.}

\begin{tabular}{|ll|}
\hline Mode of delivery & No. of patients \\
\hline Caesarean delivery & $120(75.65 \%)$ \\
\hline Normal vaginal delivery & $32(21.05 \%)$ \\
\hline
\end{tabular}

Table 2 is showing that majority of the mothers, 57 cases $(37.5 \%)$ were Para 1 while as $54(35.52 \%)$ were Para 2, $28(18.42 \%)$ had Para third. In $13(8.5 \%)$ cases, the parity was more than 4 .

Table 2: Parity.

\begin{tabular}{|ll|}
\hline Parity & No. of patients \\
\hline 1 & $57(37.5 \%)$ \\
\hline 2 & $54(35.52 \%)$ \\
\hline 3 & $28(18.42 \%)$ \\
\hline$\geq 4$ & $13(8.5 \%)$ \\
\hline
\end{tabular}

Table 3 is showing that out of 152 patients $70(46.05 \%)$ were male babies and $82(53.94 \%)$ were female babies, $145(95.34 \%)$ were breast fed and $7(4.60 \%)$ neonates were on top and mixed feeding.

Table 3: Gender distribution.

\begin{tabular}{|ll|}
\hline Gender & No. of patients \\
\hline Males & $70(46.05 \%)$ \\
\hline Females & $82(53.94 \%)$ \\
\hline
\end{tabular}

Blood group A was seen in $61(40.13 \%)$. Group B in 55 (36.18\%), Group $\mathrm{O}$ in $23(15.13 \%)$ and blood group AB in $13(8.55 \%)$. $\mathrm{Rh}$ incompatibility were excluded from the study.

Initial bilirubin estimation was done on day first postnatal day, and the range of initial bilirubin estimation was between $2.9-8 \mathrm{mg} / \mathrm{dl}$. Clinically detectable jaundice was present in $110(72.36 \%)$ patients.

Table 4: Blood group distribution of mothers.

\begin{tabular}{|ll|}
\hline Blood group & No. of patients \\
\hline A & $61(40.13 \%)$ \\
\hline B & $55(36.18 \%)$ \\
\hline O & $23(15.13 \%)$ \\
\hline AB & $13(8.55 \%)$ \\
\hline
\end{tabular}

Study outcome were defined as total serum bilirubin of greater than $17 \mathrm{mg} / \mathrm{dl}$ occurred in $14(9.21 \%)$ of patients. All 14 patients required phototherapy, but none required exchange transfusion $\mathrm{ABO}$ in-compatibility was present in one patient, none of the babies had bilirubin above 17 $\mathrm{mg} / \mathrm{dl}$ in first 72 hours of life.

Out of 152 new-borns, $101(66.44 \%)$ with serum bilirubin less than $6 \mathrm{mg} / \mathrm{dl}$ only 1 developed significant hyperbilirubinemia, were as $51(33.52 \%)$ new-borns who had serum bilirubin more than $6 \mathrm{mg} / \mathrm{dl} 13(25.46 \%)$ developed significant hyperbilirubinemia.

Table 5: Showing clinically detectable jaundice in new-borns.

\begin{tabular}{|lll|}
\hline Clinical examination & $\begin{array}{l}\text { No. of } \\
\text { patients }\end{array}$ & $\%$ \\
\hline Jaundice detectable & 110 & 72.36 \\
\hline Jaundice, not detectable & 42 & 27.64 \\
\hline
\end{tabular}

To identify acute off predicting a large no of babies at low risk of hyperbilirubenemia a Receiver Operating Characteristic (ROC) was drawn.

The ideal cut of was $<5 \mathrm{mg} / \mathrm{dl}$ as no baby below this level, developed hyperbilirubinemia. This level however identified lesser no of babies at low risk of hyperbilirubenemia. A cut off total serum bilirubin level 
of $\leq 6 \mathrm{mg} / \mathrm{dl}$ had a sensitivity of $72.46 \%$, a specificity of 72.46 , and positive predictive value of $25.49 \%$ and negative predictive value of $99 \%$.

Table 6: Showing patients with serum bilirubin $<6$ mg/dl (controls, >6 mg/dl (cases) and subsequent huperbilirubinemia.

\begin{tabular}{|lll|}
\hline $\begin{array}{l}\text { Total serum } \\
\text { bilirubin at } \\
\mathbf{2 4} \pm \mathbf{6} \text { hours }\end{array}$ & $\begin{array}{l}\text { No of infants } \\
(\%)\end{array}$ & $\begin{array}{l}\text { Infants with significant } \\
\text { hyperbilirubinemia }\end{array}$ \\
\hline$\leq \mathbf{6} \mathbf{~ m g} / \mathbf{d l}$ & $101(66.44 \%)$ & $1(<1 \%)$ \\
\hline $\mathbf{6} \mathbf{~ m g / d l}$ & $51(33.66 \%)$ & $13(25.49 \%)$ \\
\hline
\end{tabular}

\section{DISCUSSION}

Neonatal jaundice is a cause of concern for the parents as well as the clinicians ${ }^{5}$ and is the most common reason for readmission after early hospital discharge. ${ }^{6}$ Classical kernicterus has occurred in healthy terms infants who do not have a haemolytic disease or any other discernable cause of jaundice. ${ }^{7}$

This study was conducted in the Paediatrics, GB pant hospital and Department of Obstetrics /Gynacology, Lal Ded Hospital (both associated hospitals of Government Medical College, Srinagar) to assess the predictive value of total serum bilirubin measurement within 24 hours of postnatal life and subsequent hyperbilirubinemia in term new-borns.

In this study complete information was available in 152 patients. No new-born had a serum bilirubin level of $\geq 17$ $\mathrm{mg} / \mathrm{dl}$ in the first 72 hours of life. Clinically detectable jaundice was present in 110 patients $(72.36 \%)$ and, 14 patients developed significant hyperbilirubinemia requiring phototherapy. There was no evidence of haemolysis in these babies and investigations like $\mathrm{Hb}$, $\mathrm{PCV}$, Retic count were in normal range.

$37.5 \%$ mothers were Para $1,35.52 \%$ were Para 2 while as $26.92 \%$ mothers were Para 3 or more. Caesarean section was performed in $120(75.65 \%)$ mothers while as in 32 $(21.05 \%)$ mothers it was a normal vaginal delivery. In the study conducted by Agarwal et al., 54\% were caesarean deliveries and majority of the mothers ere Para 1 or 2 . These figures regarding caesarean section are slightly higher in our study that could be attributed to the fact of Lad Ded Hospital is the only territory care referral hospital for the whole valley. Pregnancy induced hypertension was seen in $13(8.5 \%)$ while as $6(3.39 \%)$ mothers had multiple gestations. These figures are similar to those observed by Agarwal et al.

No baby with initial serum bilirubin level of $\leq 5 \mathrm{mg} / \mathrm{dl}$ developed significant hyperbilirubinemia, this however identified a lesser number of hyperbilirubinemia.

A critical serum bilirubin level of $6 \mathrm{mg} / \mathrm{dl}$ was evaluated and it was found that an out of 152 new-borns 101 cases
(66.44\%) had serum bilirubin $\leq 6 \mathrm{mg} / \mathrm{dl}$ and out of these 101 cases, only one neonate later developed significant hyperbilirubinemia requiring photoherapy. 51 (33.52\%) cases had serum bilirubin $>6 \mathrm{mg} / \mathrm{dl}$ and out of these, 13 cases $(25.49 \%)$ later developed significant hyperbilirubinemia. Statically analysis was done and the results were compared between the babies with serum bilirubin $>6 \mathrm{mg} / \mathrm{dl}$ and the babies with serum bilirubin $\leq 6$ $\mathrm{mg} / \mathrm{dl}$ (controls) and it was found the bilirubin level of $>6$ $\mathrm{mg} / \mathrm{dl}$ had highest sensitivity $(92.85 \%)$ to predict the new-borns who would develop significant hyperbilirubinemia. At this critical serum bilirubin level, the negative predictive value was very high (99\%), and positive predictive value was $25.49 \%$. Similar results have been observed by Agarwal et al.

A receiver operator characteristic curve was constructed at various serum bilirubin values and it was found that a total serum bilirubin level of $\leq 6 \mathrm{mg} / \mathrm{dl}$ on day first can be used to predict the decreased risk for subsequent hyperbilirubinemia (TSB $>17 \mathrm{mg} / \mathrm{dl}$. Such infants could thus be discharged early without need to follow up for hyperbilirubinemia.

Bhutani et al. ${ }^{12}$ showed in a large cohort that infants who develop hyperbilirubinemia have serum bilirubin levels, which are in higher percentiles soon after the birth. They created percentile charts of serum bilirubin level at different post natal ages in near term and term infants who had negative direct Coombs test. They found that $6.1 \%$ of neonates had predischarge serum bilirubin $\geq 95$ percentile, $32.1 \%$ of these infants showed hyperbilirubinemia subsequently. Neonates with predischarge total serum bilirubin levels in the low-risk zone $(<40$ percentile) did not show hyperbilirubinemia subsequently. However there was an important source of bias in this study; subsequent bilirubin estimation was done in only around $25 \%$ neonates. These infants were those who came for follow up or were referred by their primary care physicians. Hence a large number of infants (almost 75\%) were not included. It is likely that infants without significant problems were not included while developing these percentile charts. We observed a minimal dropout rate that was $4.6 \%$. The dropout rate in the study done by Agarwal et al. (2002) was also low, which in agreement without study.

Apley et al. $^{8}$ (2000) in a large cohort study $(n=498)$ reported that TSB level of $>6 \mathrm{mg} / \mathrm{dl}$ in the first 24 hours predicted jaundice in all new-borns. Later Agarwal et al. also evaluated the role of the first-day serum bilirubin and subsequent hyperbilirubinemia. ${ }^{5}$ The results from the present study are consistent with previous studies done by Apley et al. (2000) and Agarwal et al. (2002). Our study population was heterogeneous. We included infants with ABO incompatibility. Oxytocin use was very high in 108 mothers $(71.05 \%)$, which is a known risk factor for hyperbilirubinemia. This had also been observed by the study done by Agarwal et al. 145 babies were exclusively breastfed $(95.34 \%)$. 
Clinical jaundice was present in $72.36 \%$ of neonates and hyperbilirubinemia was seen in $9.21 \%$ neonates. This can be explained on the basis that $71 \%$ of patients were born to mothers who had received oxytocin. ${ }^{13}$ In a study done by Agarwal et al. ${ }^{5}$ clinical jaundice was seen in $77 \%$ and hyperbilirubinemia in $10.2 \%$. These results are similar to our study.

There has been a decrease in the length of post-delivery hospital stays for new-borns discharged early are at increased risk for rehospitalisation during the neonatal period $^{14}$ and neonatal jaundice is the most common reason for readmission after early hospital discharge. ${ }^{6}$

Table 7: Showing a comparison of present study versus a study by Agarwal et al.

\begin{tabular}{|lll|}
\hline Characteristic & $\begin{array}{l}\text { Agarwal et al. } \\
(2002)\end{array}$ & $\begin{array}{l}\text { Present } \\
\text { study }\end{array}$ \\
\hline $\begin{array}{l}\text { TSB at } 24 \pm 6 \text { hours } \\
\leq 6 \mathrm{mg} / \mathrm{dl}\end{array}$ & $\mathrm{n}=136$ & $\mathrm{n}=101$ \\
\hline $\begin{array}{l}\text { TSB at } 24 \pm 6 \text { hours } \\
>6 \mathrm{mg} / \mathrm{dl}\end{array}$ & $\mathrm{n}=77$ & $\mathrm{n}=51$ \\
\hline
\end{tabular}

Table 8: Comparison of study versus previous studies for evaluating the role of critical serum bilirubin level of $6 \mathrm{mg} / \mathrm{dl}$ for subsequent hyperbilirubinemia.

\begin{tabular}{|llll|}
\hline Parameter & $\begin{array}{l}\text { Apley } \\
\text { et al. } \\
(\mathbf{2 0 0 0 )}\end{array}$ & $\begin{array}{l}\text { Agarwal } \\
\text { et al. } \\
(\mathbf{2 0 0 2})\end{array}$ & $\begin{array}{l}\text { Present } \\
\text { study } \\
(\mathbf{2 0 0 6})\end{array}$ \\
\hline Sensitivity & $90 \%$ & $95 \%$ & $92.85 \%$ \\
\hline Specificity & - & $70.6 \%$ & $72.46 \%$ \\
\hline PPV & $26.2 \%$ & $27.2 \%$ & $25.49 \%$ \\
\hline NPV & $97.9 \%$ & $99.3 \%$ & $99 \%$ \\
\hline
\end{tabular}

The present study found that a total serum bilirubin level of $\leq 6 \mathrm{mg} / \mathrm{dl}$ can be used to predict the decreased risk for subsequent hyperbilirubinemia (TSB $>17 \mathrm{mg} / \mathrm{dl}$ ) with a sensitivity of $92.8 \%$ and negative predictive value of 99\%. Such infants could thus be discharged early without the need to follow up for hyperbilirubinemia later. We found that it was possible to identify infants early who are at high risk and more importantly, those who are at low risk of subsequent hyperbilirubinemia.

\section{ACKNOWLEDGEMENTS}

The authors want to thank the parents and the guardians who consented for the participation of their children in the present study.

Funding: No funding sources Conflict of interest: None declared

Ethical approval: The study was approved by the ethics committee of Medical College

\section{REFERENCES}

1. American Academy of Paediatrics. Practice parameter management of hyperbilirubinemia in the healthy term new-born. Provisional Committee for Quality improvement and subcommittee on hyperbilirubinemia. Paediatrics. 1994;(1):558-65.

2. Mead Johnson, Johnson J. Glenview. Jaundice and your baby, 1993. Available at: www.californiawebsites.com/neo.

3. Richard E, Behrman, Robery M. Jaundice and hyperbilirubinemia in the new-born. In: Richard E, Behrman, Robery M, eds. Nelson Text Book of Paediatrics. 17th ed. Philadelphia: Saunders; 2003: 592-593.

4. Micheal T. Hinkes, John P. Cloherty. Bilirubin. In: Micheal T. Hinkes, John P. Cloherty, eds. Manual of Neonatal Care. 4th ed. New York: Little Brown \& Co; 1998: 175-178.

5. Agarwal R, Monica Kaushal. Early neonatal hyperbilirubinemia using $1^{\text {st }}$ day serum bilirubin level. Indian Paediatr. 2002;39:724-30.

6. Brown AK, Johnson L. Loss of concern about jaundice and the re-emergence of kernicterus in the era of managed care. In: Far-off AA, Klaus MH, eds. The Year Book of Neonatal and Perinatal Medicine. Philadelphia: Mosby Yearbook; 1996: 17-28.

7. Maize's MJ, Newman TB. Kernicterus in otherwise healthy breast-fed term neonates. Paediatrics. 1995;96:730-3.

8. Alpay F, Sarici SU, Tosuncuk HD, Serdar MA, Inac $\mathrm{N}$, Gokcay E. The value of the first day bilirubin measurement in predicting the development of significant hyperbilirubinemia in healthy term newborns. Paediatrics. 2000;106:E16.

9. Ashok K. Deorari. Comparison of 1994 AAP guidelines with 2004 guidelines in Indian prospective. Paper Presentation. New Delhi: CME on Neonatal Care (AIIMS); Feb, 2005.

10. Britton HL, Britton JR. Efficacy of early new-born discharge in a middle class population. Am J Dis Child. 1984;138:1041-6.

11. Waldenstrom U. Early and late discharge after hospital birth: father's involvement in infant care. Early Hum Dev. 1988;17:19-28.

12. V. I. V. Bewick, Jonathan Ball. Statistics review 13: receiver operator characteristics curves. Mathematical and Information Sciences University of Brington, Brington UK. Crit Care. 2004;8:50812.

13. Buchan P. Pathogenesis of neonatal hyperbilirubinemia after inducting of labour with oxytocin. Br Med J. 1979;2:1255-7.

14. Maisels MJ, Kring E. Length of stay, jaundice and hospital readmission. Pediatrics.1988;10:995-8.

Cite this article as: Hussain S, Gattoo IA, Najar BA, Maqbool M. First day bilirubin as a predictor of development of significant jaundice in term healthy neonates: a tertiary care hospital based study. Int J Contemp Pediatr 2015;2:356-60. 